\title{
MR. CARVALHO AND THE POST-KEYNESIANS: SCHOLAR, THEORIST, WRITER
}

\author{
Gary Dymski \\ aProfessor at the Leeds University Business School, University of Leeds. Leeds, UK. \\ ORCID: https://orcid.org/0000-0001-9667-2693 \\ Received on 16 February 2019 \\ Accepted on 20 March 2019
}

\begin{abstract}
Fernando Cardim de Carvalho's monumental intellectual legacy encompasses many elements - his teaching, his mentoring, his scholarship, and his policy activism. This essay explores Cardim's contributions to Post-Keynesian economics through the lens of his 31 publications in refereed English-language journals. After applying some bibliometric analysis to these articles, we undertake a chronological review of the themes developed in Cardim's publications on theoretical topics in Keynesian economics. This is followed by a clarification and defense of Cardim's distinctive methodology. We then undertake a chronological review of the articles containing his critical analyses of development policy. This side-by-side comparison of Cardim's theoretical and policy pre-occupations through time clarifies their close interconnection. We conclude by examining the craft of writing in Cardim's work, as he was an economist whose impact stemmed not just what he said, but from how he said it. Seeing Fernando Cardim de Carvalho's scholarship from these different angles - his multidimensional contributions as a scholar, as a theorist, a critic, and as a crafter of prose - permits a full appreciation of both the range and depth of his work as a Keynesian economist.
\end{abstract}

KEYWORDS: Cardim de Carvalho; Keynes; real time; uncertainty; liquidity; finance/ funding; development; Brazil; financial system.

JEL CODES: B31; E12; E5; O11.

Corresponding author: Gary Dymski

E-mail address: g.dymski@leeds.ac.uk 


\section{CARVALHO E OS PÓS-KEYNESIANOS: ACADÊMICO, TEÓRICO, ESCRITOR}

RESUMO: O monumental legado intelectual de Fernando Cardim de Carvalho abrange muitos elementos - ensino, orientação, pesquisa e ativismo político. Este ensaio explora as contribuições de Cardim à economia pós-keynesiana através das lentes de 31 publicações em periódicos de referência em língua inglesa. Após aplicar algumas análises bibliométricas a esses artigos, realizamos uma revisão cronológica dos temas desenvolvidos nas publicações de Cardim sobre temas teóricos da economia keynesiana. Isto é seguido por um esclarecimento e pela defesa da metodologia distintiva de Cardim. Em seguida, realizamos uma revisão cronológica dos artigos que contêm suas análises críticas da política de desenvolvimento. Essa comparação lado a lado das preocupações teóricas e políticas de Cardim ao longo do tempo mostra como essas dimensões estão conectadas entre si. Concluímos examinando o ofício de escrever na obra de Cardim, pois ele era um economista cujo impacto sobre o campo decorreu não apenas do que ele disse, mas de como ele o disse. Ver a pesquisa de Fernando Cardim de Carvalho sob esses diferentes ângulos - suas contribuições multidimensionais como estudioso, como teórico, crítico e como artesão de prosa permite uma apreciação completa da abrangência e profundidade de seu trabalho como economista keynesiano.

PALAVRAS-CHAVE: Cardim de Carvalho; Keynes; tempo real; incerteza; liquidez; financiamento; desenvolvimento; sistema financeiro; Brasil. 
Our wills and fates do so contrary run,

That our devices still are overthrown; Our thoughts are ours, their ends none of our own.

- William Shakespeare,

Hamlet (Act 3, Scene 2), quoted in Fernando Cardim de Carvalho (2002-03, p. 204)

The ability to read new meanings in a work of art may depend precisely on its own ability to touch on fundamental problems for humankind, for which solutions are sought for now as in the past. ... a central question in all [Shakespeare's] plays... is an exceedingly modern one: how can any individual control his or her own destiny and give meaning to his or her own existence? The problem is choice, of course. But to be able to choose, one must be free. (...)

Freedom is the capacity to create one's destiny.

Shakespeare's permanence, of course, also has to do with craft. Shakespeare was an able playwright. His plays are highly entertaining. But one cannot ignore how strong an experience it is to read the texts.

- Fernando Cardim de Carvalho (2002-2003, p. 190)

\section{INTRODUCTION ${ }^{*}$}

In 1994, Polygram Records released a compilation of the music of Chico Buarque, one of the poet laureates of MPB. His voluminous catalogue spanned four separate CDs, each emphasizing one side of his artistry: O Trovador, O Amante, O Politico, O Cronista. A catalog of the writings of Fernando Cardim de Carvalho would cover a similarly wide span. A man of his times, like Chico Buarque, he too was a chronicler and a 'politico' - a political commentator. As an economist, he was a scholar, a theorist, a critic, and a writer. The peculiar power of his written work lies in the fact that it weaves scholarly and theoretical insights into simple and powerful prose.

Can there be another economist in any era who would find an exact analogy to John Maynard Keynes' writings on the 'fundamental problems' in twentieth-century economies in William Shakespeare's sixteenth-century play about the tragedy of choice? Or who so thoroughly extracted further insights from Keynes' texts after they had already apparently been so deeply mined? Or who penned such accomplished prose in two languages? Only Fernando. His written work consistently demonstrated

\footnotetext{
* This paper has been written in loving memory of Fernando Cardim de Carvalho (1953-2018).
} 
the power of bringing to the practice of economics the learning of the scholar, the subtlety of the accomplished theorist, and the craft of the writer.

This essay focuses on one portion of Cardim's legacy: his scholarly contributions - and specifically his 31 publications in refereed English-language journals - as a PostKeynesian economist. ${ }^{1}$ Section 1 sets the stage by applying some bibliometric analysis to these articles. Section 2 undertakes a chronological review of the themes he developed in the publications that examine theoretical topics in Keynesian economics. Section 3 explores Cardim's distinctive methodology as a theorist. Section 4 turns to the subset of articles containing his critical analyses of development policy. Section 5 then extracts lessons from the craft of Cardim's writing, as his impact stemmed not just what he said, but from how he said it. Section 6 briefly concludes.

A personal note. Fernando Cardim de Carvalho and I began our friendship at the 1996 Post-Keynesian conference in Knoxville, Tennessee. Fernando brought me to Rio de Janeiro in 1997 for an international conference at the Federal University of Rio de Janeiro, forever altering my life's trajectory. He had a similarly profound effect on many people, especially his students. His vigorous scholarship, engagement with research councils and academics across the world, and dedication to his current and former supervisees nurtured a national resurgence of Keynesianism in Brazil. He provided his students with a role model worthy of emulation. Cardim's exquisitely ironic dissections of economic dilemmas and political absurdities, delivered with dry humor and that world-weary sigh, were unforgettable. Post-Keynesian economist, friend, story-teller, father, connoisseur of music and literature, citizen of the world, grandpa: one essay on his legacy can tell only part of the story.

\section{CARDIM'S REFEREED ENGLISH-LANGUAGE PAPERS: SOME BIBLIOMETRICS}

While his research encompassed many topics, Cardim always returned to Keynes: he published his first English-language paper on Keynesian theory in 1983, and his last in 2016; and his two Keynesian books were separated in time by 23 years (1992, 2015). How did Cardim approach his practice as a Keynesian monetary macroeconomist? To make this question manageable, we focus our attention on the 31 papers he published in English in refereed journals: 12 in the Journal of Post Keynesian Economics and

\footnotetext{
1 Throughout this article, Fernando is referred to as 'Cardim, the name by which his colleagues knew him; citations are to Carvalho, the surname he used in his publications in English.
} 
seven in Brazilian journals. These papers appear in part 1 of the bibliography contained at the end of this essay, organized by category and date of publication.

A modest bibliometric investigation of these 31 papers yields some preliminary insights. These texts divide readily into three topic areas: 12 on Keynesian theoretical topics; 12 on issues confronting developing economies; and seven on other applied issues. Cardim engaged with each topic area at each stage of his career. Between 1983 and 1993, he published four theoretical papers and two on development; between 1995 and 2003, three theoretical and three applied papers, and five development papers; and between 2009 and 2018, five papers on theoretical and development topics, and four on applied topics.

In the body of these articles, the most frequently cited authors are John Maynard Keynes, 74 citations, an average of 2.5 per article; Cardim himself, 41 citations, an average of 1.4 per article; Paul Davidson and Jan Kregel, 24 citations, a 0.8 average; Hyman Minsky, 13 citations; GLS Shackle, nine; and John Hicks and Michal Kalecki, eight each. Other authors cited three times or more in these 31 papers are: Axel Leijonhufvud (7); Milton Friedman (6); Charles Kindleberger, Karl Marx, Bertil Ohlin, Larry Summers, and James Tobin (5); Joan Robinson and Nicholas Kaldor (4); Tom Asimakopulos, Barry Eichengreen, and Robert Solow (3).

Some patterns emerge. Several authors are cited more frequently in the 12 theory papers than in the other 19; in decreasing order, Keynes (31), Kregel (17), Davidson (14), Minsky (9), Hicks (7), Ohlin, Shackle (5), Robinson, Kaldor, Leijonhufvud (4), Asimakopulos, and Tobin (3). Cardim's close relation to his Rutgers mentors Davidson and Kregel is strongly evident, ${ }^{2}$ as is his habit of elaborating ideas in Keynesian monetary economics by focusing on a few of its central contributors.

Three further points can be made. First, all but two of Cardim's 20 self-references to his theoretical papers (as designated in this paper) occur in his other theoretical papers. And 21 references to his own non-theoretical papers are cited only in his other non-theoretical papers. In effect, his theoretical investigations are held in a separate realm than his inquiries into applied topics. As noted below, his non-theoretical papers do contain references to Keynes, Davidson, Kregel, and other theorists, but not to his own work on economic theory. Secondly, almost entirely absent from these citation lists are currently active Post-Keynesian authors. Apart from his Rutgers supervisors, and with the further exception of Julio Lopez (4), no other currently-active authors are cited more than once or twice in this collection of papers. Third, he favors, as analytical His published work also acknowledges two other members of the Rutgers economics faculty: Alfred Ei-
chner (CARDIM, 2002-2003) and Nina Shapiro (CARDIM, 1984-1985). 
terms, words and phrases with a long Keynesian pedigree, such as liquidity and uncertainty. He never uses the term 'financialization' in these articles, nor does he use the term 'non-ergodic', which Paul Davidson (1978) introduced into Post-Keynesian economics as a way of characterizing Keynesian uncertainty.

In summary, Cardim treated theoretical work as a privileged realm of inquiry, and continually returned to it throughout his career. He privileged historically-recognized authors and established terms, not more recent authors or terms of usage.

\section{CARDIM, THE SCHOLAR}

We now consider the sequential development of themes and ideas in the 12 theoretical papers listed in part 1a of the bibliography. Each demonstrates that, for Cardim, theorizing proceeds through scholarship. They contain 83 references to Keynes, Davidson, Kregel, Shackle, Minsky, and Hicks, double the average number of references to these authors in his non-theoretical papers. Cardim's theoretical ideas are viewed through the lens of these foundational figures' writings.

The first paper in this list (1983-1984) focuses on the treatment of time in the work of Shackle and Sraffa. Cardim observes the importance of 'real time' in Shackle - the fact that economic decision-makers must make decisions whose consequences they cannot know because of the passage of time between commitment and realization. This is, of course, an analytical embodiment of the idea of fundamental uncertainty so forcefully analyzed by Keynes (1936, Chapter 12) and Davidson (1978). For Sraffa, by contrast, time is a merely logical construct, as his model develops a long-run approach on the basis of the 'center of gravity' of production processes, paying no attention to decisions about whether and how much to produce. Cardim notes that time in Sraffa's model is closer to mainstream economics' general equilibrium approach than to Keynes'.

Cardim's second paper (1984-1985) also contrasts short-run and long-run approaches within the Post-Keynesian tradition, pointing out the contradictions that arise when models attempt to simultaneously incorporate both short-run and long-run dynamics. He ends by concluding that "It is the dichotomy between short and long run models that is rejected." And of the two approaches, it is 'gravity center' (long run) models that are especially problematic, because they "assum[e] the ability to postulate results without being able to indicate the ways they can be attained" (1984-1985, p. 232).

The third listed paper (1988) elaborates on Keynes' writing on probability, focusing on the interaction of belief, uncertainty, and knowledge. He concludes by countering the view (without attribution) that Keynes' approach to uncertainty is nihilistic. He rejects this and concludes by recognizing the "theoretical intractability of long-term 
expectations, where the human logic of belief predominates over the formal logic of probability" (1988, p. 80). Cardim's fourth paper (1990) explicitly examines Keynes' conception of the long run; it begins with Keynes' own recognition (and that of his followers) that, if his view of economic dynamics is restricted to short-run forces alone, then it can be asserted that in the long run the (non-Keynesian) forces emphasized in classical theory will come to the fore. Cardim concludes that what matters is "long-run expectations rather than long-period values and there is no way the environment can make those compatible, even in the long run" (1990, p. 288). The two can coincide only when it is reasonable to restrict agents' expectations to those required by a long-period model, but such restrictions are only a temporary and very special case.

Taken together, these first four theoretical papers critically analyze the problematic co-habitation within Post-Keynesian theory of uncertainty-informed (short-run) and center-of-gravity (long-run) approaches. The next set of papers shifts attention from disputes among Keynesians to issues that differentiate Keynesian and neoclassical approaches to macroeconomic theory.

Cardim's fifth paper (1996) seeks to make sense of several interrelated controversies - in the 1930s, 1950s, and 1980s - over Keynes' "finance motive" and the determination of interest rates. At the root of both controversies are the relationships among investment and savings, and between (short-term) finance and (long-term) funding. Cardim shows that while money and hence credit (finance) is endogenous, savings may constrain investment if the real-time dimension of these processes are affected by shifting agent expectations in the face of uncertainty. ${ }^{3}$ This paper demonstrates how the loanable-funds doctrine underlies the neoclassical assertion that savings determines investment. The loanable-funds doctrine, in turn, emerges in a world without fundamental uncertainty: outcomes may be subject to stochastic variation, but they follow known (or discoverable) probabilities and thus are effectively certaintyequivalent. In this world, agents don't have to rely on beliefs rooted in conventions to assess risk-return tradeoffs - they can consult their own risk preferences. The many impacts of uncertainty on agent perception and behavior - such as shifting liquidity preferences due to changing assessments of uncertain events, as well as changing degrees of confidence in these assessments - are excluded definitionally from consideration. In such a world, any divergences between aggregate demand and supply 3 The endogeneity of money itself is not sufficient to anchor a Keynesian analysis; Arestis and Sawyer (2003)
point out that many neoclassical macroeconomic models incorporate a tame form of money endogeneity. 
are readily taken care of through adjustment processes (that is, Say's Law holds). Bank financing plays a purely secondary role, and financial market efficiency is guaranteed.

In effect, preserving the finance/funding distinction, insofar as it is linked to autonomous bank activity and agents' behavior under uncertainty, installs the problem of aggregate demand at the center of the debate over the financing of investment. Will agents with fragile, convention-based expectations in uncertain environments maintain their investment expenditure plans and keep their liquidity preferences in check? What this shows then is that what's present and absent in macro models matters - Keynesian models can insert the autonomy of aggregate demand in different ways. One is to postulate structurally inadequate expenditures. Another is to highlight the inherent fragility of expenditure planning once the factors impinging on financial decisions are fully taken on board.

Cardim's sixth listed theoretical paper (1997a) also focuses on the financing/ funding problematic. It critiques Wicksell's supply-demand-equilibrium approach to interest-rate determination, which leads back to loanable-fund theory; it also argues that financial innovations in the institutional basis of lending and borrowing (securitization, expanded money-market funding of financial intermediaries' asset positions, and so on) do not eliminate, but instead accentuate, the importance of the finance/funding distinction in investment and savings behaviour. Cardim's ninth paper (2012) in this sequence, written post-crisis, takes up the question of why neoclassical theorists have so thoroughly resisted the idea that investment creates savings. His point of departure is Wicksell's 'natural rate of interest', on which current neoclassical models of monetary policy rely, as is readily seen in Woodford (2003, Chapter 4) and Woodford (2010). Since pre-Keynesian and contemporary neoclassical theory share both Wicksell and an equilibrium approach to the macroeconomy, Cardim - relying as ever on sharp observations by Keynes - points out that Wicksell's 'natural rate' ideas overlook the realtime logic of investment and savings processes. While the growing complexity and opacity of financial linkages demand analytical attention - "credit caused the money veil to become thicker" (2012, p. 203) - it remains the case that "investment expenditures require money, not income or saving" (2012, p. 208). So

finance, from a Keynesian perspective, is therefore a far more complex function than merely intermediating saving or capital. Finance creates and distributes liquidity. (CARVALHO, 2012, p. 212)

The $11^{\text {th }}$ paper (2015) in this list, a contribution to the inaugural issue of the Brazilian Keynesian Review, presents a theoretical overview of Keynes' economics. It argues against the 'mechanistic' and 'fiscalist' views of Keynes' General Theory and 
asserts that the most important theoretical innovations therein represent "developments or applications of his views on behavior under uncertainty" (2015, p. 46). And Keynes defended the idea that "experience was the strongest determinant of expectations."

Keynes's approach to expectations and uncertainty, thus, attempted to transcend at the same time a mechanistic bias whereby agents responded in automatic ways to specified stimuli and the assumption of irrationality. Keynes's point is that individuals do make non-empty choices because they are choosing among outcomes of their own creation but once the outcomes are identified the choice among them is rational. (CARVALHO, 2015, p. 48)

The $12^{\text {th }}$ and final listing among Cardim's theoretical papers (2016a) explores the importance of liquidity preference and the finance/funding distinction in understanding financial systems, as well as the inadequacy of the investment/savings view adopted in Gurley and Shaw (1960). He concludes by recalling Keynes' discussion of a 'dilemma' involving liquidity, financial markets, and investment in General Theory:

the liquidity dilemma is intrinsic to the dynamics of a monetary economy. The same financial structures that allow productive investment and capital accumulation, and economic growth, to reach the levels characteristic of modern capitalist economies are also those where fragilities are accumulated that ultimately cause deep crises, such as the one that began in the U.S. economy in 2007 and has since spread throughout most of the world. (CARVALHO, 2016a, p. 306)

\section{CARDIM, THE THEORIST}

We now turn from Cardim's findings in economic theory to how he constructed his theoretical analysis. This is not a topic about which he wrote; he never authored a text purely on method. We might surmise that for Cardim himself, his method was perfectly transparent: to carefully analyze valued (if contested) passages in core texts, to carefully examine the historical setting and institutional context of a given problem, and to illuminate the questions in debate using the analytical tools one has chosen and attempted to refine.

What immediately stands out is that Cardim's approach to theory focused on making sense of Keynes' own meanings. As noted above, he cites the work of four leading Post-Keynesians (Kregel, Davidson, Shackle, and Minsky) extensively, and 
uses other sources very selectively. ${ }^{4}$ He uses these leading Post-Keynesians' work not to extend the ground of Keynesian theory, but to better understand Keynes' theoretical purposes and findings. With one exception (CARVALHO, 2013), he did not engage explicitly with contemporary debates in Post-Keynesian theory.

At the same time, he was not sycophantic about Keynes' work. He never referred to himself as a true interpreter of 'the master', as Skidelsky (2009) terms Keynes; in fact, he cast a skeptical eye on whatever he studied, including his own insights. This does not mean he lacked confidence in his own views. On the contrary: he did not slavishly follow Keynes and sometimes pointed out differences between what Keynes meant and what he wrote. As Kregel put it in his preface to Cardim's 2016 book:

Cardim de Carvalho is not an uncritical student of Keynes, and he notes that a large part of the problem is to be found in Keynes's own presentation of his new approach in the General Theory and subsequent attempts at clarification. (CARVALHO, 2016d, p. xii)

This scholarly, confident reconstruction of some of Keynes' key ideas provided a solid conceptual basis for his writing on applied topics. And these theoretical explorations were not 'one and done' - he explored core Keynesian ideas throughout his career. This can be shown very precisely. The second paragraph of his very first publication reads, in full:

The importance of an unambiguous statement on the concept of time cannot be exaggerated. Until one deals explicitly with the concept of time one cannot analyze the concept of changes in the economic system. (CARVALHO, 1983-1984, p. 265)

Twenty-eight years later, the concluding section of his 2016 theoretical paper includes this passage:

Liquidity is ... what allows individuals and entities to protect themselves, to some extent, against the uncertainties of the future....

As with other essential arguments of Keynes's economics, the liquidity dilemma is intrinsic to the dynamics of a monetary economy. (CARVALHO, 2016a, p. 305-306)

4 In the 11 theoretical papers on which we focus (again, leaving aside the Shakespeare paper), Cardim has an average of just over four references to these four named authors; in the other 18 articles on non-theoretical topics, these authors are cited only 1.4 times on average. 
The first quoted sentence, from the 1983-1984 paper, launches a reflective essay on Shackle's interpretation of core Keynesian ideas; the second set of sentences - between which is sandwiched a long quote from Keynes - extends ideas developed by Keynes. And the very last paragraph of Cardim's 2016 book, Liquidity Preference and Monetary Economics, reads thus:

The main policy implication advanced by liquidity preference theory, as, in fact, by all known Keynesian variants of economic thought is that austerity is not the proper strategy to achieve recovery. Managing aggregate demand to induce full employment, while preserving price stability, among other objectives, remains the Holy Grail of Keynesian economics. It is the only way to stimulate businesses to produce and to invest, maintaining activity levels and employment and accumulating capital in order to improve the lives of, potentially, everybody. (CARVALHO, 2016d, p. 138).

So everything is there at both the beginning and the end of his theoretical journeying: real time and uncertainty are crucial components of the 'liquidity dilemma', which is at the heart of 'changes in the economic system'/'the dynamics of a monetary economy'. And these micro-foundations, which elaborate the decisional dimension of economic relations, are adequate to demonstrate the importance of aggregate demand and the need to manage it to achieve full employment.

This brings us to a second defining element of Cardim's work as a theorist. He did not return to the foundational level underlying macrostructural relations uncertainty, real time, liquidity preference - because they provided puzzles that could be solved by sufficiently clever managers or investors, not to mention economists. The foundational level of analysis on which he concentrated his attention was, for him, a never-solved problem. Agents could see their confidence fall away in a lunge for liquidity at every age and at every time. No system design can avoid this decisional moment. It is simply how things are. The problem of choice under uncertainty always confronts us: "how can any individual control his or her own destiny and give meaning to his or her own existence?", as he put it in the Shakespeare paper quoted at the beginning of this essay.

Cardim and debates about Post-Keynesian economics. Cardim shaped his theoretical approach at a time when the nature of Post-Keynesian theory was being hotly debated. Marc Lavoie tossed Cardim into the middle of this debate when he classified Cardim's 1992 book on Keynesian theory, in a 1993 review essay, as "(American) Post Keynesianism (or Keynesian fundamentalism)" (LAVOIE, 1993, p. 1300), expressing surprise that a book by a Keynesian economist from Latin America would not highlight the centrality of inequality and class conflict (1993, p. 1302-1303). 
Hamouda and Harcourt (1988) had identified three principal strands of PostKeynesian economics: an American (later, 'Wall Street') approach, focused on monetary issues, real time, and uncertainty; a 'Cambridge' approach, exploring models of aggregate investment-savings behavior under various conditions, including a Kaleckian variant in which the roles of capitalists and workers are starkly defined in zero-sum terms; and a Sraffian version explicitly detailing the production and distributional structures of the capitalist economy. Harcourt (1999, p. 32) termed these "horses for courses." These three strands differed considerably on precisely the issues which Cardim emphasized - short-run versus long-run, and the importance or inessentiality of money and financial relations, in particular.

Walters and Young (1997) argued that the Hamouda and Harcourt big-tent view of Post-Keynesianism led only to its theoretical incoherence. A full-fledged debate ensued. ${ }^{5}$ Lavoie, who clearly preferred the 'Cambridge' approach, published a 2009 paper arguing that the stock-flow consistent model could reconcile the 'Cambridge' and 'Wall Street' approaches. Cardim never followed this suggested path. The 31 articles considered here contain no references to "stock-flow consistent models."

Lavoie's critique, however, rests on a misunderstanding of Cardim's approach to Post-Keynesian theory. He did not use mathematical models, and did not apologize for that, and pursued his own practice with rigor. At the same time, he did not engage in internecine warfare with those Post-Keynesians who did explore Cambridge- or Sraffian-inspired models. To draw again from the Shakespeare paper above, "[f]reedom is the capacity to create one's destiny." He created his own approach to theory, without denying others the freedom to create their own Keynesian paths. Without explicitly saying so, he followed Harcourt's "horses for courses" characterization of the breadth of Post-Keynesian theory.

Keynesian economics or the economics of Keynes? The gap that opened in the 2000s between Lavoie's advocacy of stock-flow consistent models and Cardim's unrepented non-mathematical approach his economic ideas was not new. On the contrary, Axel Leijonhufvud (1968) had already identified this gap 40 years earlier. In a book cited four times by Cardim in the papers discussed here, UCLA economist Leijonhufvud contrasted 'Keynesian economics' - the formal model-based approach - with the 'economics of Keynes', which emphasizes the substance of Keynes' work.

Leijonhufvud's wise book foresaw the demise of Keynesian economics; by "linking our definition of the 'Keynesian tradition' to ... the standard simultaneous equation model" (LEIJONHUFVUD, 1968, p. 7), a plain-vanilla Keynesian economics had

\footnotetext{
5 See, for example, Arestis, Dunn, and Sawyer (1999) and Dunn (2000).
} 
emerged which was stripped of any informing "[v]ision of what the world is like" (1968, p. 6). Thus, the truce between two groups which had had a "peaceful but nonetheless uneasy coexistence" (1968, p. 7) until then - specifically, to use his terminology, the 'Revolutionary Orthodoxy' and the 'Neoclassical Resurgence' - was certain to shatter. Of course, his two groupings represented the Cambridge Keynesians and the proto-New Classical economists. The way forward, in Leijonhufvud's view, was to unlink Keynes from a Keynesian economics that had nothing to do with his vision and to rediscover the economics of Keynes. And indeed, 'Keynesian economics' disappeared amidst the supply-side shocks and stagflation of the tumultuous 1970s.

Leijonhufvud's distinction perfectly describes Cardim's modus operandi. Cardim sought to stay connected to Keynes' vision; in his writing, theoretical discussions about Keynesian ideas begin with foundational concepts - time and uncertainty - not with a pre-commitment to particular models. Cardim always works from the problem of how expectations formed in the face of uncertainty are crucial, time-varying determinants of how people - as consumers or as decision-makers in firms - will act or react: will they spend or save, will they hold the line on their expectations or lose hope. These behavioral reactions underlie - microfound, so to speak - the idea that aggregate demand matters independently of aggregate supply and thus provide the conceptual basis for a Keynesian approach. Uncertainty and agents' shared beliefs are fragile and can support robust equilibria or overwhelm them because they are formed in real-time environments.

Model versus theory versus science in economics. The point of theory, seen from this entry-point, is not to reduce core conceptual ideas to formulas or variables, but to identify the critical variables and relationships in any economic environment. How they play out depends on evolving and specific institutional contexts. This brings us another aspect of Cardim's approach: he clearly differentiates theory from models that express theoretical ideas. He works on the former, not the latter.

In dictionary definitions, the distinction is clear. The Oxford English Dictionary defines 'theory' as "the conceptual basis of a subject or area of study", and 'model' as "a simplified or idealized description or conception of a particular system, situation, or process, often in mathematical terms, that is put forward as a basis for theoretical or empirical understanding." However, this distinction is lost on many economists, especially in mainstream macroeconomics as it has evolved in the wake of the Lucas critique (LUCAS, 1975). To have a theory, for many practitioners, is to have a model; without a (fully specified formal) model, one is not a macroeconomist. This view, which has become so pervasive in the space of monetary macroeconomics in which Cardim's work unfolds, has a long history.

For many economists, mathematical methods occupy pride of place at the center of economic theory: the proof of the existence and uniqueness of equilibrium orchestrated 
by Von Neumann (1945) and Debreu (1959), among others (INGRAO and ISRAEL, 1990) became the impossible standard by which all theoretical enterprise in economics was subsequently judged. This standard hit macroeconomics with special force. Roger Farmer presciently affirmed the centrality of general equilibrium throughout all of economic theory when he wrote, "the future of macroeconomics is as a branch of applied general equilibrium theory" (FARMER, 1993, p. 1). In mainstream economics, macroeconomics was indeed collapsed into microeconomics, as can be explicitly seen in the baseline dynamic stochastic general-equilibrium (DSGE) model, which depicts aggregate behavior through the actions of a single representative agent.

This same pressure toward mathematical models as a standard of communication and mark of excellence has been felt, to a lesser extent, in Post-Keynesian economics. Lavoie's recent 'bible' of Post-Keynesian economics (LAVOIE, 2014) focuses largely on elaborating formal models, especially the stock-flow consistent framework, and pays virtually no attention to the issues highlighted in Cardim's theoretical work (uncertainty, liquidity, and so on).

This rests on another confusion - the idea that to be mathematical is to be more scientific. If we turn, however, to the two non-archaic, non-obsolete definitions of 'science' in the Oxford English Dictionary: "a discipline, field of study, or activity concerned with theory rather than method;" and "a branch of study that deals with a connected body of demonstrated truths (...) comprehended by general laws, and incorporating trustworthy methods for the discovery of new truth in its own domain." The latter definition sets Popperian falsifiability as the criterion for science; this is not a criterion that macroeconomic models can meet. The former definition links 'science' with 'theory', and so we are back to the idea of 'science' as a broader terrain of investigation and discovery, within which models compete to make sense of things. As McCloskey (1998) puts it, "good science is good conversation."

The limits of mathematical models in describing the fragility of economic behavior. The idea that theory is necessarily a broader domain than any models that might represent it, and requires considered exchange, is readily seen. Consider the problem of replacing the previously accepted, New Consensus' formal macroeconomic model, which failed to foresee the most profound economic crisis since the Great Depression (TOOZE, 2018). This failure reminded us that a model is a fragile construction, whose coherence depends not just on the relations it specifies, but also on what it has left out, unintentionally or by design.

We might start with the fact that the baseline DSGE model in use before the crisis excluded financial crises by design, as was acknowledged by a defender of DSGE methods in a dialogue recorded by Driffill (2011). One might attempt to patch this model by suggesting that a disturbance in the imagined non-crisis path - a financial 
friction (WOODFORD, 2010) - was the problem. As long as no other shocks occurred, the crisis is disturbed as a one-time anomaly. Of course, as shocks multiply, the model that imagines a smooth trajectory of an economy through time as a baseline scenario becomes clearly more inadequate since its estimates are invalidated by an external environment that does not play by the (model's own) rules.

So much for the neoclassical macroeconomic model. Suppose we want to leave it behind and instead construct a model that allows for endogenous failure(s). This can be done either by describing the complex or chaotic master logic at the system level or by populating the model with individual, imperfectly-informed agents who grope forward, as full rationality lies beyond their reach. Is there any way to choose among them? Each will have infinite solutions and be infinitely malleable in the hands of gifted technicians. And in any case, neither alternative model quite captures the economics of Keynes that Cardim was prioritizing.

A key characteristic of complex-systems models is that they can break down under different parameterizations; a key characteristic of agent-based models is that the agents cannot know the state of the system and must have behavioral rules specified in advance of the game. But the point of the foundational dilemmas that Cardim is emphasizing is that the decisions made by agents facing uncertainty and real-time conditions are changeable and unstable themselves. The agents at the bottom of the chain of connections in the model aren't stable; so, any model premised on pre-given preferences or decision-rules will not be accurate.

The point of Cardim's theoretical approach, then, is to focus on the unstable behavioral foundations of macroeconomic relations. This instability arises from the existential circumstances faced by people and firms in real-world, real-time settings, circumstances that are not model-dependent and not simple. As our review of Cardim's scholarly insights showed, models can only capture portions of theory; and when they try to do too much (combining short-run and long-run dynamics, for example), they can mislead.

Cardim's approach, his continual return to the core condition of uncertainty, constitutes a warning about simplification. To be tractable, models must necessarily simplify decision processes or economic and social structures. Reality is more always more complex, and the point of theory is to create a space for considering the challenges thrown up by real-world conditions. Cardim's repeated discussions of the funding- $v s$ finance problem are meant to show that the endogeneity of money is not a 'get out of reality free' card. A satisfactory theory has to be richer than any model representing the key ideas of that theory.

It is important to grasp the implications of Cardim's conclusion that aggregate demand matters in his final theoretical paper (CARVALHO, 2016a). The idea that aggregate demand matters normally emerges, in Post-Keynesian economics, in models 
with the pregiven structural (fixed-behavior) possibility of a shortage of effective demand (for example, Kaleckian models with workers and capitalists having different consumption propensities). Cardim showed, in that paper, that the lack of effective demand can emerge due to the forces operating on the foundational nexus 'beneath' demand. The former path is model-dependent; the latter not only resists formalization but does not require the specification of a formal model.

\section{CARDIM, THE CRITIC}

Like Keynes, Cardim's immersion in the nuances of theory reflected both the delight he found in unpacking conceptual puzzles and his belief that the resolution of fine points in theory mattered hugely for the design of economic policy. Indeed, the majority of his refereed English-language publications apply insights to real-world challenges: twelve papers examine the problems of developing economies; seven others, economic policy in the global system. ${ }^{6}$

His papers on development topics focus almost entirely on Brazil, and appear in three clusters, reflecting that countries' sequential challenges as it moved from the 1980 s into the 2000s. Cardim first published two papers $(1992,1993)$ on the causes and consequences of 'strato-inflation' - sustained hyper-inflation - in Brazil. These papers counter the Monetarist view that inflation is simply a matter of excessive money creation, which can be cured by 'turning off the taps', by demonstrating that stratoinflation emerged in Brazil due to an intertwined set of institutional and historical circumstances that lead to a resilient system of indexation and adaptation, wherein instability becomes perversely stabilized. Cardim then published three papers (2000a, 2000b, 2001) that described the historical evolution of the strategies and crisismanagement methods of the International Monetary Fund (IMF), with special attention to the Mexican and East Asian crises of the latter 1990s. These papers argued that the IMF's diagnosis that developing nations' currency crises were due to structural problems led it to interfere with the "autonomy of developing economies to adopt the policies they would see as favorable to growth" (CARVALHO, 2000c, p. 3).

The combined impact of the strato-inflation period and of IMF-mandated structural reforms was that the 1994 Real plan that restabilized prices and exchange rates was accompanied by the opening of exchange accounts and of banking markets

\footnotetext{
6 Due to space limitations, Cardim's paper on 'new developmentalism' (2018a) and his seven papers (1995,
} $1997 b, 1997 c, 2007,2008,2016 c$, and 2018b) on the latter applied topic are not discussed here. 
to foreign entry. Cardim wrote two papers (2000c, 2002b) on the historical opening of Brazil to foreign banking. The key question at issue was whether these banks' presence would yield efficiency and performance gains for the Brazilian economy; Cardim argued that the preliminary evidence showed no such gains; actually, domestic banks were quicker to take advantage of technical progress than foreign banks. This research was followed by a paper (2002c) exploring Brazil's failure to consider capital controls of any kind in the Real era, and thus to protect against capital flight.

In 2009, Cardim added two papers to this register of frustration about development policy: one (2009b) highlighting the absence of the preconditions for financing development, and another (2009c) documenting the failure of the Southern Cone 'common market' in South America (Mercosur) to give serious attention to intraregional co-development. His final refereed paper on a development topic (2016b), written after years of deterioration in the Brazilian political and economic scenario, warned that his homeland was 'looking into the abyss'.

These 12 papers, then, mapped the evolving situation of the Brazilian economy during Cardim's career as an economist. What is remarkable here is that Cardim presents detailed renderings of the historical circumstances pertaining to the policy contexts he is describing. These renderings always attempt to sort political developments and pressures from economic forces; the author's political beliefs are not on display, not the point of the exercise. Instead, attention focuses on conclusions about economic decisions and processes rooted in the Keynesian approach to economic theory that - as we have seen - Cardim was continually refining. Comparing the chronological list of Cardim's theoretical concerns (section 2) with the chronological account of his writings on development policy (this section) demonstrates their thematic interconnection. His writing on uncertainty, belief, and knowledge are followed by his articles on stratoinflation; his writing on finance/funding are followed by his papers on foreign banking and financial openness; and his writing on the logic of macrofinancial systems, and the role therein of liquidity and financing motives, is paralleled by his reflections on the consequences of incoherent development for Brazil's economic future. So, like Keynes, Cardim was continually developing theoretical insights in the service of policy, while drawing policy conclusions on the basis of his theoretical insights.

\section{CARDIM, THE WRITER}

This section makes several points about why Cardim is so effective as a crafter of prose. As he wrote regarding Shakespeare's plays, in the passage that began this paper, "one cannot ignore how strong an experience it is to read the texts." This will not only 
explain why the experience of reading Cardim's texts is itself so strong but clarify how Cardim plays his role as an author. That role can be simply described: to invite the reader into a terrain of discourse that has been shaped by the key contributions of intellectual forebears. In this, he was fastidious and precise.

Some patterns in this authorial role can be clarified with the help of some further bibliometrics. We noted before that Cardim refers to his own theoretical essays in his other theoretical essays - never in his non-theoretical work. There is a two-step process at work. In his theoretical work, as noted before, he examines the work of foundational figures in Keynesian economics to clarify core theoretical concepts. Those core terms emerge clearly from the frequency with which they appear in the 12 theoretical papers reviewed here: decision and Keynes appear in all 12; uncertainty, real time, and expectations in 11 of the 12; and liquidity and aggregate (or effective) demand in ten. In the papers on development topics considered here, the most frequently-appearing terms are: inflation and expectations (9 of 12); liquidity, banks, and IMF (8); and uncertainty, decision, and Keynes (7). In the papers on other applied topics, the most frequently-appearing terms are: effective (aggregate) demand, and Keynes (7); inflation and uncertainty (6); and decision, expectations, banks, and fiscal policy (5). That is, he builds up a base of concepts and uses it to explore a range of applied topics.

His exposition devotes far more attention to elaborating on the differing positions of specific authors on a given issue than to blanket commentary. He used Keynes' writing and the disputes in which Keynes engaged as his points of reference; he was not explicitly interested in defining Keynesian theory. As noted before, he did not treat even his favorite authors' words as sacred texts, nor did he ever claim that his own interpretations were more accurate than others'. This modesty in registering claims about his own work extends to other contemporaries: as noted, he seldom references contemporaries. While this lends a backward-looking aspect to his scholarly references, it stands in stark contrast to the current trend toward defensively or sycophantically over-referencing recent contributions.

Another characteristic of Cardim as a writer is that he invariably treats the reader as a companion on a journey, not an observer at a distance. His texts ask their readers to consider how they think and decide, how he or she experiences real-time choices in the world. In making uncertainty central in his own theoretical conception, he is refusing the idea of theory as a scalpel with which to dissect reality; uncertainty is instead both a point of departure and return for his readers. Cardim's texts implicitly seek to transcend the convention wherein the reader is provided with the author's map of the structure of a world; they put their readers into that world, along with the author.

There is, then, an existential element in much of Cardim's work, especially in his theoretical reflections. When he builds ideas to shape our thinking, he invariably 
highlights both the dilemma of the individual and the economic relations and structures in society. This comes, as discussed above, from Cardim's focus on the foundational level of analysis. By insisting on the centrality of expectations, uncertainty, decisions, and time, he is pulling economists back, again and again, to the interior psychological moments and behavioral dilemmas present within the moments that unfold inside any and every economic structure. Byung-Chul Han might describe this as restoring the role of "memory as a dynamic, living process" in which "different levels of time intersect and influence each other" (HAN, 2017, p. 67); Keynes' placing uncertainty and liquidity at the core of his theory, a choice Cardim affirmed, means that the agent and his or her decisions can never be taken as fixed and pre-given; agents - their memories, fears, and hopes - are always dynamic, always themselves in motion.

This brings us to the question of whether Cardim's approach to economics is scientific. That depends, as we have seen, on how we understand science. If science consists of either a series of empirical observations or of theorems and lemmas derived from convex logics in closed spaces, then it can be left those who are skilled at running experiments and solving formal systems.

In the preceding section, the brief exploration of the definitions of key terms theory, model, and science - suggests there is room for a more expansive understanding, one that affirms McCloskey's view of "good science as good conversation." Indeed, if a given model is one representation of a theoretical possibility, and theory represents a map of possibility, not a certainty, then science does require dialogue and debate, and it encompasses ambiguity. And a theory can be a terrain of inquiry, a set of questions, a form of memory.

Those engaged in the sciences investigating the social world would be well-advised to consider the consequences of taking a model for a theory: it is just one step to confusing science with ideology. The outstanding recent example of how this latter confusion can have devastating consequences occurred when Alan Greenspan, former chair of the US Federal Reserve, testified before the Congressional oversight committee. In an October 25, 2008 session led by US Congressman Henry Waxman (Democratic Party - California), the following exchange ensued:

Chairman Waxman. Dr. Greenspan, I am going to interrupt you. The question I had for you is you had an ideology. ... Now, our whole economy is paying its price. You feel that your ideology pushed you to make decisions that you wish you had not made?

Mr. Greenspan. ... [I]deology is, is a conceptual framework with the way people deal with reality. Everyone has one. You have to. To exist, you need an ideology... What I am saying to you is, yes, I found a flaw, I don't know how significant or permanent 
it is, but I have been very distressed by that fact. But if I may, may I just finish an answer to the question----

Chairman Waxman. You found a flaw?

Mr. Greenspan. I found a flaw in the model that I perceived is the critical functioning structure that defines how the world works, so to speak.

Chairman Waxman. In other words, you found that your view of the world, your ideology, was not right, it was not working.

Mr. Greenspan. Precisely. That's the reason I was shocked, because I had been going for 40 or more years with very considerable evidence that it was working exceptionally well.

Turning once more to the Oxford English Dictionary, the term 'ideology' in question here has four meanings, of which two are pertinent: "the study of ideas;" and "a systematic scheme of ideas, usually relating to politics, economics, or society and forming the basis of action or policy; a set of beliefs governing conduct." Mr. Greenspan obviously worked with the second definition of ideology and confused his "model of the model" with a scientific view of markets affirmed by theory. While it may be too optimistic to imagine that this leopard will change his spots, those beasts that remain in the climate-challenged jungle must think better if they are to survive another " 40 or more years." 7

Cardim's conversational approach to science, his open theoretical stance, and his sometimes transcendent relationship with his readers are evident in many places in his texts. As we have seen, his acceptance of the ambiguous character of the very building blocks of his science (the individual) led him into unusually intimate companionship with his readers. Consequently, it is no surprise to see that Cardim laced the concluding sections of his papers with insights that, if not strictly derived from those papers' line of thought, generate almost three-dimensional conversations with his readers/coadventurers.

This is readily seen in the conclusion to his Shakespeare paper, which asks the reader to consider "the deep personal experience that reading [Shakespeare's work] signifies to begin with" (CARVALHO, 2002-2003, p. 218). And consider the concluding sentence to his 2018 theoretical paper:

\footnotetext{
Greenspan and Woolridge (2018, p. 444-447) argue that enhanced bank capital, not better regulation, will restore efficiency in the US financial system.
} 
The same financial structures that allow productive investment and capital accumulation, and economic growth, to reach the levels characteristic of modern capitalist economies are also those where fragilities are accumulated that ultimately cause deep crises, such as the one that began in the U.S. economy in 2007 and has since spread throughout most of the world. (CARVALHO, 2016, p. 306)

This sentence invites the reader to jump to reflections about the contemporary crisis, in a manner that comes close to breaking the third wall between author and reader. That this can be done in a manner consistent with the practice of science (in McCloskey's sense) is clearest in the final section of Cardim's article (2009a) about Keynes' precautionary demand for money. In a subsection entitled "Conclusion: why should we care?", Cardim writes:

One may think that this whole discussion about the disappearance of the precautionary demand for money from the GT is just another curiosum, an arcane game of words and labels to entertain hagiographers of Keynes. In fact, it is not. Generations of economists have been trained in macro and monetary economics through the use of money and demand-supply models where stable relations between money demand and its determinants, income and the interest rate, are assumed by construction. Anybody whose macroeconomics training was based on the use of IS/LM models never actually heard about the ways in which perceived uncertainty can affect the demand for money and, thus, the level of interest rates. (CARVALHO, 2009a, p. 722)

\section{CONCLUSION}

In considering what makes Cardim unique as a Post-Keynesian theorist, the context matters: he developed his own practice as a macroeconomist during a time period in which formalization and sophisticated empirical methods came to virtually define the field of macroeconomics. Some economists fought back by emphasizing that the mathematical formalisms mask economists' use of metaphors and appeals to the art of persuasion (Deirdre McCloskey); others incorporated explicit attention to methodology into their body of work (Sheila Dow). Post-Keynesian macroeconomics has not been immune to these trends.

Cardim never engaged in these trends to formalization and advanced empirical methods. He simply wrote, as he lectured, as a monetary macroeconomist. He so thoroughly occupied that theoretical ground that he never wrote an essay expositing his own methods. This does not mean that he did not care for how he wrote what he 
had to write. A person as immersed in literature, cinema, and music as Cardim could only focus as much on the way of knowing as much as on the knowing. Writing about that was a different matter, however.

This essay has jumped into this gap by exploring Cardim's theoretical ideas as well as the way he presented them. Our point of entry has been the uncontroversial insight that his written work interwove the four elements of scholar, theorist, critic, and writer. There is much to learn from in this combination. Cardim's theoretical insights derived from the evolving policy dilemmas thrown up by the Brazilian political economy insights he insisted on drawing out of his reading of the work of John Maynard Keynes.

Then, in the end, we have the elegance of his prose. The permanence of his words, as he wrote of Shakespeare, "has to do with craft." This was his 'science, if that is science. There is much that Post-Keynesian economists, as well as others, can learn from studying the written works that Cardim left us. "Freedom is the capacity to create one's destiny." We create our own understandings, as well as our way of reaching those understandings.

\section{REFERENCES}

Part 1 - List of the 30 refereed articles authored by Fernando Cardim de Carvalho that comprise the focus of analytical attention in this paper. Articles are organized by category and year:

\section{a) Keynesian theory}

CARVALHO, F. J. C. On the concept of time in Shacklean and Sraffian economics. Journal of Post Keynesian Economics, v. 6, n. 2, p. 265-280, 1983-1984.

CARVALHO, F. J. C. Alternative analyses of short and long run in Post Keynesian economics. Journal of Post Keynesian Economics, v. 7, n. 2, p. 214-234, 1984-1985.

CARVALHO, F. J. C. Keynes on probability, uncertainty, and decision-making. Journal of Post Keynesian Economics, v. 11, n. 1, p. 166-180, 1988.

CARVALHO, F. J. C. Keynes and the long period. Cambridge Journal of Economics, v. 14, n. 3, p. 277-290, 1990.

CARVALHO, F. J. C. Sorting out the issues: the two debates (1936/37; 1983-86) on Keynes's finance motive revisited. Revista Brasileira de Economia, v. 50, n. 3, p. 312-327, 1996.

CARVALHO, F. J. C. Financial innovation and the Post Keynesian approach to the 'process of capital formation'. Journal of Post Keynesian Economics, v. 19, n. 3, p. 461-487, 1997a.

CARVALHO, F. J. C. Decision-making under uncertainty as drama: Keynesian and Shacklean themes in three of Shakespeare's tragedies. Journal of Post Keynesian Economics, v. 25, n. 2, p. 189-218, 2002-2003. 
CARVALHO, F. J. C. Uncertainty and money: Keynes, Tobin and Kahn and the disappearance of the precautionary demand for money from liquidity preference theory. Cambridge Journal of Economics, v. 34, n. 4, p. 709-725, 2009a.

CARVALHO, F. J. C. Aggregate savings, finance and investment. European Journal of Economics and Economic Policies: Intervention, v. 9, n. 2, p. 197-213, 2012.

CARVALHO, F. J. C. Keynes and the endogeneity of money. Review of Keynesian Economics, v. 1, n. 4, p. 431-446, 2013.

CARVALHO, F. J. C. Keynes on expectations, uncertainty and defensive behaviour. Brazilian Keynesian Review, v. 1, n. 1, p. 44-54, 2015.

CARVALHO, F. J. C. On the nature and role of financial systems in Keynes's entrepreneurial economies. Journal of Post Keynesian Economics, v. 39, n. 3, p. 287-307, $2016 \mathrm{a}$.

\section{b) Development challenges}

CARVALHO, F. J. C. The resilience of high inflation: recent Brazilian failures with stabilization policies. Journal of Post Keynesian Economics, v. 15, n. 1, p. 109-124, 1992.

CARVALHO, F. J. C. Strato-inflation and high inflation: the Brazilian experience. Cambridge journal of Economics, v. 17, n. 1, p. 63-78, 1993.

CARVALHO, F. J. C. The IMF as crisis manager: an assessment of the strategy in Asia and of its criticisms. Journal of Post Keynesian Economics, v. 23, n. 2, p. 235-266, 2000a.

CARVALHO, F. J. C. The changing role and strategies of the IMF and the perspectives for the emerging countries. Brazilian Journal of Political Economy, v. 20, n. 1, p. 3-18, 2000 b.

CARVALHO, F. J. C. New competitive strategies of foreign banks in large emerging economies: the case of Brazil. Banca Nazionale del Lavoro Quarterly Review, v. 53, n. 213, p. 135-69, 2000c.

CARVALHO, F. J. C. On the ownership of reform proposals. How social policies found their way into IMF adjustment programs. Econômica, v. 3, n. 1, p. 67-94, 2001.

CARVALHO, F. J. C. The recent expansion of foreign banks in Brazil: first results. Latin American Business Review, v. 3, n. 4, p. 93-119, 2002a

CARVALHO, F. J. C. Strengthening the defenses of the Brazilian economy against external vulnerability. International Journal of Political Economy, v. 32, n. 4, p. 35-48, 2002 b.

CARVALHO, F. J. C. Financing development: Some conceptual issues. International Journal of Political Economy, v. 38, n. 4, p. 5-24, 2009 b.

CARVALHO, F. J. C. "Economic integration and development in Latin America: perspectives for Mercosul. Journal of Post Keynesian Economics, v. 32, n. 2, p. 235-248, 2009c.

CARVALHO, F. J. C. Looking into the abyss? Brazil at the mid-2010s. Journal of Post Keynesian Economics, v. 39, n. 1, p. 93-114, 2016 b.

CARVALHO, F. J. C. Financial flows and the New Developmentalism. Brazilian Journal of Political Economy, v. 38, n. 1, p. 115-24, Jan./Mar. 2018a. 


\section{c) Global and applied economics}

CARVALHO, F. J. C. The independence of central banks: a critical assessment of the arguments. Journal of Post Keynesian Economics, v. 18, n. 2, p. 159-175, 1995.

CARVALHO, F. J. C. Economic policies for monetary economies. Revista de Economia Política, v. 17, n. 4 , p. $68,1997 b$

CARVALHO, F. J. C. The corridor hypothesis and inflationary regimes. Revista de Economia Contemporânea, v. 1, n. 2, p. 39-58, 1997c.

CARVALHO, F. J. C. Are full employment policies obsolete? International Journal of Political Economy, v. 36, n. 3, p. 5-23, 2007.

CARVALHO, F. J. C. Keynes and the reform of the capitalist social order. Journal of Post Keynesian Economics, v. 31, n. 2, p. 191-212, 2008.

CARVALHO, F. J. C. Is this 'it'? An outline of a theory of depressions. Brazilian Journal of Political Economy, v. 36, n. 3, p. 451-469, 2016c.

CARVALHO, F. J. C. Arguments for austerity, old and new: the British Treasury in the 1920s and the Bundesfinanzministerium in the 2010s. European Journal of Economics and Economic Policies, v. 15, n. 3, p. 262-288, 2018 b.

Part 2 - List of all additional references

ARESTIS, P.; SAWYER, M. The nature and role of monetary policy when money is endogenous. Working Paper, Levy Economics Institute of Bard College, Annandale-on-Hudson, n. 374, Mar. 2003.

ARESTIS, P.; DUNN, S. P.; SAWYER, M. Post Keynesian economics and its critics. Journal of Post Keynesian Economics, v. 21, n. 4, p. 528-50, 1999.

CARVAlHO, F. J. C. Mr. Keynes and the Post Keynesians: Principles of macroeconomics for a monetary production economy. Cheltenham: Edward Elgar, 1992.

CARVALHO, F. J. C. Liquidity preference and monetary economics. London: Routledge, 2016d.

DAVIDSON, P. Money in the real world. 2. ed. London: Macmillan, 1978.

DEBREU, G. The theory of value. New York: Wiley, 1959.

DOW, S. C. Post Keynesianism and critical realism: What is the connection? Journal of Post Keynesian Economics, v. 22, n. 1, p. 5-33, 1999.

DRIFFILL, J. The future of macroeconomics: general discussion. The Manchester School, Supplement, p. 1-38, 2011.

DUNN, S. P. Wither Post Keynesianism? Journal of Post Keynesian Economics, v. 22, n. 3, p. $343-$ 364,2000 .

FARMER, R. The macroeconomics of self-fulfilling prophecies. Cambridge: MIT Press, 1993.

GREENSPAN, A.; WOOLRIDGE, A. Capitalism in America: a history. New York: Penguin, 2018. 
HAMOUDA, O.; HARCOURT, G. Post-Keynesian economics: from criticism to coherence? Bulletin of Economic Studies, v. 40, n. 1, p. 1-33, 1988.

HARCOURT, G. C. 'Horses for courses:' the making of a post-Keynesian economist. In: HEERTJE, A. (Ed.). The makers of modern economics. Cheltenham: Edward Elgar, 1979, v. 4, p. 32-69.

INGRAO, B.; ISRAEL, G. The invisible hand: economic equilibrium in the history of science. Cambridge: MIT Press, 1990.

KEYNES, J. M. The general theory of employment, interest, and prices. London: Macmillan, 1936.

LAVOIE, M. Book review of 'Mr Keynes and the Post Keynesians: principles of economics for a monetary production economy' Journal of Economic Issues, v. 27, n. 4, p. 1300-1303, Dec. 1993.

LAVOIE, M. "Toward a Post-Keynesian consensus in macroeconomics: reconciling the Cambridge and Wall Street views". In: HEIN, E.; NEICHOJ, T.; STOCKHAMMER, E. (Eds.). Macroeconomic policies on shaky foundations: wither mainstream economics? Marburg: Metropolis, 2009.

LAVOIE, M. Post-Keynesian economics: new foundations. Cheltenham: Edward Elgar, 2014.

LEIJONHUFVUD, A. Keynesian economics and the economics of Keynes. Oxford: Oxford University Press, 1968.

LUCAS, Jr., R. E. An equilibrium model of the business cycle. Journal of Political Economy, v. 83, n. 6, p. 1113-44, 1975.

MCCLOSKEY, D. The rhetoric of economics. 2. ed. Madison: University of Wisconsin, 1998.

SKIDELSKY, R. Keynes: The return of the master. London: Public Affairs Books, 2009.

TOOZE, A. Crashed: how a decade of financial crises changed the world. London: Allen Lane, 2018.

UNITED STATES HOUSE OF REPRESENTATIVES. Hearing before the Committee on Oversight and Government Reform. House of Representatives, One Hundred Tenth Congress, Second Session, October 23, 2008. Washington, D.C.: US Government Printing Office, 2008.

VON NEUMANN, J. A model of general economic equilibrium. Review of Economic Studies, v. 13 , n. 1, p. 1-9, 1945.

WOODFORD, M. Interest and prices: foundations of a theory of monetary policy. Princeton: Princeton University Press, 2003.

WOODFORD, M. Financial intermediation and macroeconomic analysis. Journal of Economic Perspectives, v. 24, n. 4, p. 21-44, Fall 2010.

YOUNG, B.; YOUNG, D. On the coherence of Post-Keynesian economics. Scottish Journal of Political Economy, v. 44, n. 3, p. 329-51, 1997. 